\title{
Petrophysical Analysis of the Mpera Well in the Exploration Block 7, Offshore Tanzania: Implication on Hydrocarbon Reservoir Rock Potential
}

\author{
Juma M. Mheluka, Gabriel D. Mulibo* \\ Department of Geology, University of Dar es Salaam, Dar es Salaam, Tanzania \\ Email: *gmbelwa@yahoo.com
}

How to cite this paper: Mheluka, J.M. and Mulibo, G.D. (2018) Petrophysical Analysis of the Mpera Well in the Exploration Block 7, Offshore Tanzania: Implication on Hydrocarbon Reservoir Rock Potential. Open Journal of Geology, 8, 803-818.

https://doi.org/10.4236/ojg.2018.88047

Received: June 8, 2018

Accepted: August 1, 2018

Published: August 3, 2018

Copyright $\odot 2018$ by authors and Scientific Research Publishing Inc. This work is licensed under the Creative Commons Attribution International License (CC BY 4.0).

http://creativecommons.org/licenses/by/4.0/ (c) (i) Open Access

\begin{abstract}
The present study provides evaluation and estimation of petrophysical parameters and assessment of lithology and their thicknesses in order to characterize present reservoir rocks at Mpera well located in Exploration Block 7, deep offshore Tanzania. To achieve the objectives the wire-line logs, Techlog program was used for assessment, analysis, computation and interpretations of petrophysical parameters and results were integrated through interpretation of well logs. The results from wire-line logs reveal three (3) non hydrocarbon-bearing reservoir rocks i.e., Mpera splay (sandstone), Mpera deep sand 1 (sandstone and limestone) and Mpera deep sand 2 (sandstone and limestone) with gross thickness of $94.335 \mathrm{~m}, 28.905 \mathrm{~m}$ and $12.967 \mathrm{~m}$ respectively. The average permeability values of the reservoir rocks were $9.47 \mathrm{mD}$, $6.45 \mathrm{mD}$ and $4.67 \mathrm{mD}$, while average porosity values were $14.57 \%, 17.4 \%$ and $16.75 \%$, with average volume of shale $25.7 \%, 23.5 \%$ and $9.7 \%$ at Mpera splay, Mpera deep sand 1 and Mpera deep sand 2 respectively. These results signify poor permeability; good porosity and good quality reservoir in terms of volume of shale. Fluid type defined in the reservoirs was basically water. High water saturation $(90.6 \%$ - 97.7\%) in the reservoir zones of the Mpera well indicates that the proportion of void spaces occupied by water is high, thus, indicating less than $10 \%$ hydrocarbon saturation. The findings indicate that Mpera well reservoir rocks are of low quality with non-hydrocarbon bearing such that it is not potential for hydrocarbon production.
\end{abstract}

\section{Keywords}

Reservoir, Hydrocarbon, Lithology, Mpera, Offshore 


\section{Introduction}

Tanzania offshore basins were formed during the breakup of Gondwana, which also resulted in the formation of most known coastal basins in the World including Australia coastal basins [1], the Norian-age (228.4 - 209.5 Ma) sediments of the upper Flagstone, Bench Formation of the Antarctica [2], Madagascar coastal basins [3] and the East African coastal basins [4] [5] [6]. Tanzania offshore basins which are part of East African coastal basins together with other coastal sedimentary basins (Figure 1) were formed between 205 and $157 \mathrm{Ma}$ as the consequence of drifting of Madagascar from East Africa along the Davie Fracture zone [7] [8]. Extensional and compressional periods controlled by strike-slip movement of the Davie Fracture Zone [9], created many sedimentary basins and multiple petroleum systems. The exploration Block 7, which is the study area where Mpera well is located, lies within deep offshore basins that are known to be petroliferous for hydrocarbon exploration [4] [10]. This hydrocarbon potentiality is evidenced by the presence of hydrocarbon shows depicting both at the surface and subsurface in different parts around the area. Variation of geochemical properties of these hydrocarbon shows indicates that multiple petroleum systems are active in Tanzania [11], although hydrocarbon shows have been observed in various parts around Block 7 .

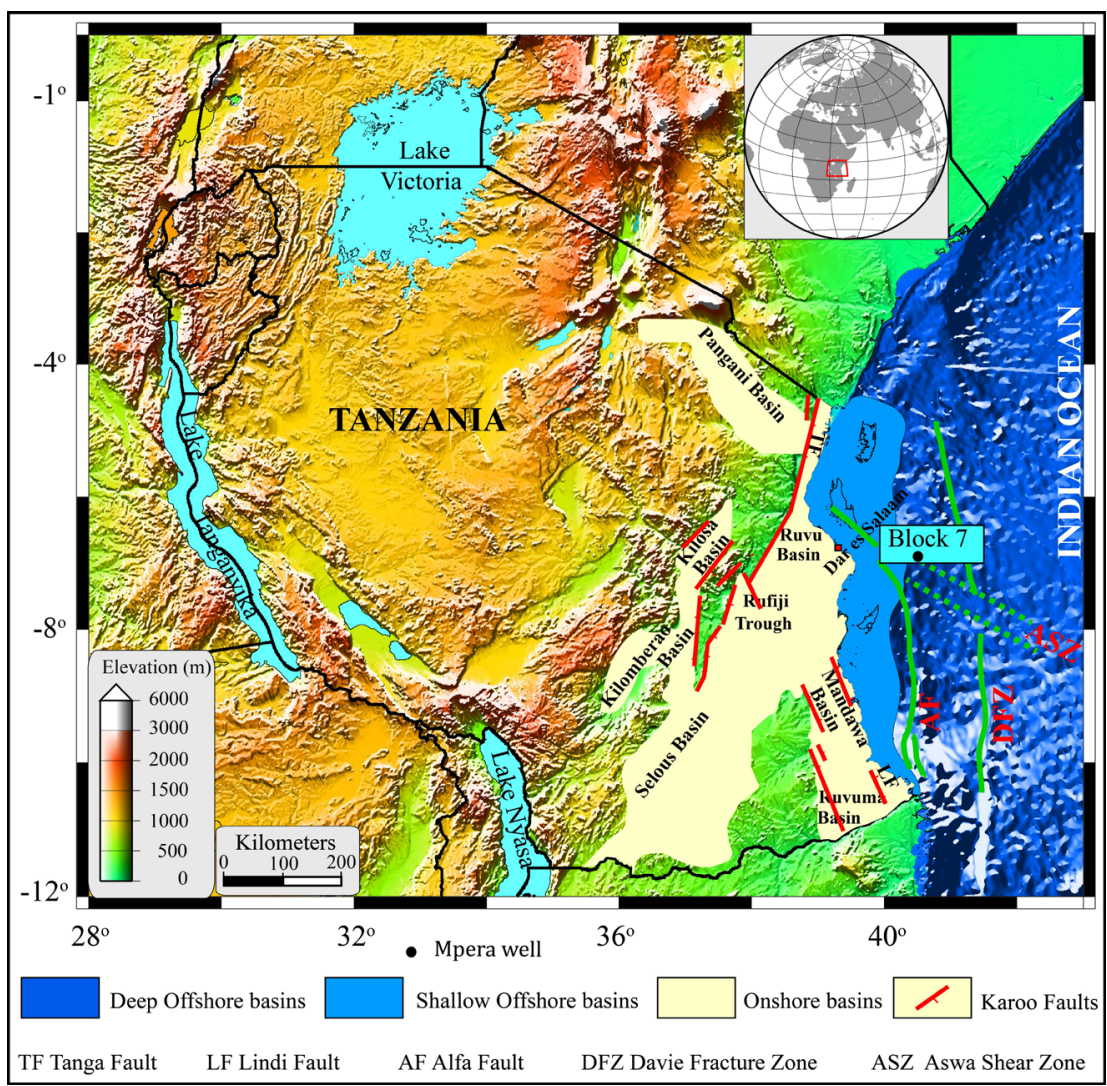

Figure 1. A topographic map of Tanzania (ETopo1; [14]) showing the Tanzania coastal basin (onshore and offshore basins) and the major structure of the basins (modified after [9]). The figure also shows the location of Block 7 where Mpera well is located. 
The Tanzania offshore basins are mainly composed of thick Mesozoic and Tertiary successions with the thickness of approximately $4000 \mathrm{~m}$, which overlap the continent-ocean [12] and occur parallel to the coast and are joined with large, down-to-the-basin faults, which demarcate the present coastline (Figure 1). Despite the presence of hydrocarbon discoveries in various parts along the Tanzania offshore basins, reservoir units and their thicknesses intersected by Mpera well, in exploration Block 7 are not well known. Moreover, the petrophysical characteristics of the reservoir rocks at Mpera well are not well estimated. Furthermore reservoir rock units intersected by the borehole and their petrophysical characteristics are not well established.

Petrophysical logs provide most of the subsurface data available to an exploration geologist. The interpretation of Petrophysical logs is one of the most useful and important tools available to a petroleum geologist. Logs help to define physical rock characteristics such as lithology, porosity, pore geometry, and permeability. Furthermore Logging data are also used to identify productive zones, to determine depth and thickness of zones, to distinguish between oil, gas, or water in a reservoir, and to estimate hydrocarbon reserves [13]. These characteristics are important in providing information about the reservoir qualities, which can be integrated with other data to provide a guide and enhanced exploration and development of the reservoir. This study therefore have used well logs to characterize reservoir rocks through analysis of petrophysical parameters, of reservoirs encountered at Mpera well in exploration Block 7, offshore Tanzania so as to assess the quality of the reservoirs in the area.

\section{Geology and Tectonic Setting}

\subsection{General Geological Setting}

The exploration Block 7 is located offshore northeastern Tanzania and connects the southern portion of the Pemba-Zanzibar Sub-basin and the northern section of the Mafia Deep Sub-basin, which is part of the Tanzania Coastal Basin (Figure 1). The formation of sedimentary basins offshore Tanzania is related to the breakup of Gondwana and strike slip fault, which caused drift of Africa and Madagascar continental block [8]. The area is strongly affected by two-stage break-up of Gondwana, which began at about $300 \mathrm{Ma}$ [6] [7] [15] [16] [17].

The first phase of rift occurred from 300 to $205 \mathrm{Ma}$ creating extended rift systems across the continent that are filled with thick siliciclastic and carbonate sediments of the Karoo Group. The second phase started from about 205 to 157 Ma marked the actual fragmentation of the Gondwana and was accompanied by the extrusion of extensive flood basalts [7]. From about $157 \mathrm{Ma}$, active sea-floor spreading in the Western Somalia and Mozambique Channel Basins separated Gondwana into West (Africa and South America) and East (Antarctica, India and Sri Lanka, Madagascar, Seychelles and Australia) blocks [18] [19]. The drifting, which commenced in the Middle Jurassic along the Davie Fracture zone continued throughout the Late Jurassic and ceased in the Santonian at $\sim 85 \mathrm{Ma}$ 
[20].

Regional structural trend of Tanzania coastal and offshore follows the Tanga and Lindi Permo-Triassic faults, which strike in the NNE-SSW and NNW-SSE respectively, with some young onshore faults oriented along the same trends (see Figure 1). The Utete-Tangalala and the Aswa lineaments are also present in the coastal basin. The offshore structural features are post Karoo faults and the trend has been rejuvenated from older ones. The orientation structural features run parallel to the present coastline [20].

\subsection{Stratigraphic Information of the Basin}

The stratigraphic sequence and architecture of the Tanzania offshore basin, which spans from Jurassic to Neogene, was established from well data and 3D seismic data [21] (Figure 2). Within the stratigraphic sequence of offshore Tanzania, Mpera well in exploration Block 7 lies within the Paleogene sequence (Figure 2), and can be correlated with the sequence stratigraphy from the southern Tanzania offshore wells.

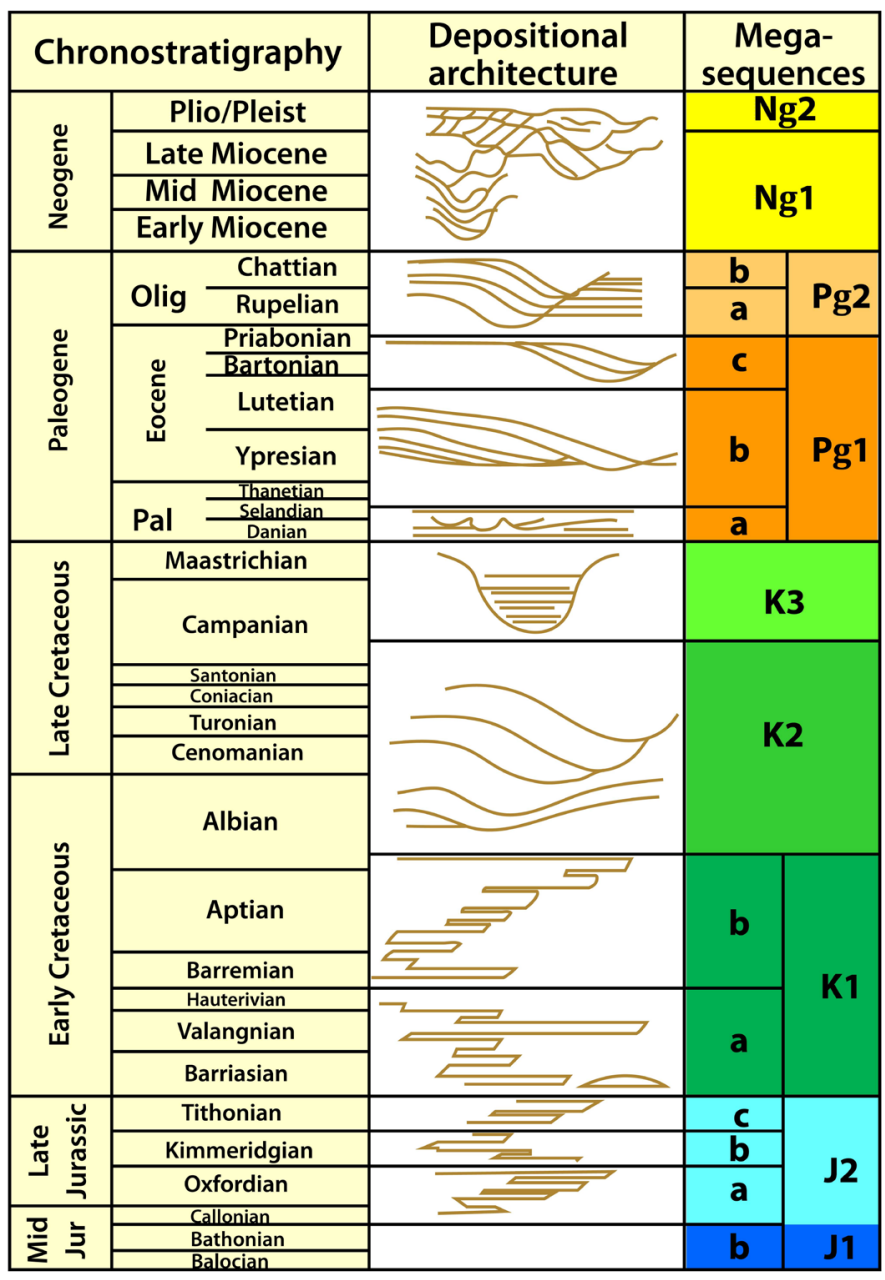

Figure 2. Sequence stratigraphy and depositional architecture of offshore Tanzania (modified from [22]). 
The exploration Block 7 encompasses three prominent tectonic elements [9]. The first tectonic element is the Davie Fracture Zone (DFZ) that represents the right-lateral wrenching along which Madagascar move. West of this zone, synrift sediments of the Triassic to Early Jurassic age are overlain by post Middle Jurassic to recent post rift sequence [21]. The second one is the Aswa shear zone, which is a reactivated Precambrian NW-SE oriented feature extending onshore. The last tectonic element in Block 7 is the Sea Gap Fault, which is visible in the Cretaceous sequence but does not extend into the Paleogene.

\section{Material and Methods}

The objectives of this study have been accomplished using wire-line logs from Mpera well provided by Tanzania Petroleum Development Company (TPDC). Wire-line logs, which were available for analysis, are gamma-ray log, caliper log, corrected bulk density, density log, neutron log, resistivity logs. The wire-line logs collected from Mpera well were used to analyze the petrophysical parameters of the reservoir rock using Techlog software version 2013.4.0.1 established by Schlumberger. The quantitative values of porosity, saturation, reservoir gross thickness, net to gross ratio, bulk volume of water, volume of shale and permeability were estimated using empirical formulas. The Gamma ray log has been used to calculate volume of shale where porosity was calculated from density log. The fluid saturation was estimated using resistivity logs and permeability was estimated using Timur equation.

\subsection{Petrophysical Methods}

\subsubsection{Lithological Identification from Gama Ray Log}

Gamma ray logs were used for the identification of sandstone and claystone/shale lithology as it normally reflects the shale content of the formation due to its radioactive materials [22] [23] [24]. In the identification of the lithology the gamma ray reading using different API values was used. The gamma ray readings and their corresponding lithology used in this study are given in Table 1.

\subsubsection{Lithological Identification from Neutron-Density Logs}

Lithology identification using neutron-density logs has been explained in details by Rider [26]. The idealized neutron-density logs combination is based on responses of values of density and neutron logs in a corresponding depth showing different separation characteristic. In shale/claystone lithology, neutron-density gives a signature of positive separation of neutron and density logs while in sandstone lithology it gives a signature of negative separation of neutron and

Table 1. Relative gamma ray values for common sedimentary rocks, used in the interpretation of lithology in gamma ray readings [25].

\begin{tabular}{cccccc}
\hline Lithology & Sandstone & Shale & Dolomite & Limestone & Coal \\
\hline Gamma ray value in API unit & $15-30$ & $60-150$ & $15-40$ & $15-40$ & $15-150$ \\
\hline
\end{tabular}


density logs. In this study these signatures were used in identification of lithology where positive separation means high value of neutron and density logs and negative separation means low value of neutron and density logs.

\subsubsection{Lithological Identification from Caliper Log}

In general caliper log was used in connection with the data collected by other petrophysical logs for the precise determination of the lithology intersected by the borehole. In this study the lithology was identified as shale when the borehole diameter was larger than the bit size, and sandstone when the borehole diameter was smaller than the bit size.

\subsubsection{Lithological Identification from Resistivity Logs}

The three subcategories of resistivity (i.e., Shallow resistivity, Deep resistivity, and Medium resistivity logs) were used in lithology identification such that when the formation is impermeable (shale) there is no separation between the deep and shallow resistivity logs. Shale formations indicate lower resistivity than the sandstone formations due to the presence of bound water in clays. In contrast the separation between two resistivity logs demonstrates the permeable zone (sandstone). The high resistivity in tight sandstone/carbonate rocks is related to cementation or compaction whereas porous sandstones, which are filled with water, show low resistivity.

\subsection{Estimation of Petrophysical Parameters}

\subsubsection{Volume of Shale Estimation from Gama Ray Log}

The volume of shale was estimated using non-linear equation sigmoidal function, which reduces the uncertainty in Vshale calculation, therefore having positive impact in the original oil or gas in place and reserves [27]. The best method that reduces the uncertainty in Vshale calculation is from Clavier [28] and was used in this study for estimation of volume of shale.

$$
V_{s h}=1.7-\left[\left(3.38-\left(I_{G R}+0.7\right)^{2}\right)\right]
$$

But:

$$
I_{G R}=\frac{G R_{\log }-G R_{\min }}{G R_{\max }-G R_{\min }}
$$

where $I_{G R}$ is the Gamma ray index, $V_{s h}$ is the shale volume fraction calculated using the $G R_{\log }$ response, $G R_{\log }$ is the gamma ray reading from the log, $G R_{\min }$ is the minimum gamma ray from the log and $G R_{\max }$ represents maximum gamma ray from the log.

\subsubsection{Porosity Estimation}

The estimation of porosity in this study was done using density log, which was calculated from empirical formula. The first step was to obtain value of the matrix density and shale density that where obtained from max and min values of density $\log$ respectively by assuming the density of fluid to be $1.1 \mathrm{~g} / \mathrm{cm}^{3}$. Princi- 
pally, density logs measure the bulk density of the formation. It is a direct tool that is used to derive the porosity of the formation because the bulk density of a rock depends on porosity and density of the fluids filling pores. Porosity parameter was determined by switching the bulk density readings obtained from the formation density log within each reservoir and then put into Equation (3) for calculating the porosity.

$$
\phi=\frac{\rho_{m a}-\rho_{b}}{\rho_{m a}-\rho_{f}}
$$

where $\phi$ is the porosity calculated though the density log, $\rho_{m a}$ is the matrix density, $\rho_{b}$ is the bulk density as obtained from the log and $\rho_{f}$ of $1.1 \mathrm{~g} / \mathrm{cm}^{3}$ is the fluid density.

\subsubsection{Water Saturation Estimation from Indonesian Equation}

Indonesian equation is the one of the suitable model that is used to calculate the water saturation in shaly sand reservoirs introduced by Poupon and Leuveaux [29]. This was a modification of Simandoux equation to strike to a better evaluation of water saturation in fresh water formation in Indonesia. However, it is now subsequently found to be useful in other areas. The Indonesian formula is given as;

$$
S_{w}=\left\{\left[\left(\frac{V_{s h}^{2-V_{s h}}}{R_{s h}}\right)^{\frac{1}{2}}+\left(\frac{\phi_{e}^{m}}{R_{w}}\right)^{\frac{1}{2}}\right]^{2} R_{t}\right\}^{\frac{-1}{n}}
$$

where $S_{w}=$ Water saturation, $V_{s h}=$ Volume of shale, $R_{s h}=$ Resistivity of shale, $\phi_{e}=$ Effective porosity, $R_{w}=$ Water resistivity of formation, $m=$ Cmentation coefficient, $n=$ Saturation capacity and $R_{t}=$ Real resistance.

\subsubsection{Determination of Hydrocarbon Saturation}

After obtaining water saturation, the hydrocarbon saturation was computed by subtracting the value of water saturation from $100 \%$, using the following formula.

$$
S_{h}=\left(100-S_{w}\right) \%
$$

\subsubsection{Permeability Estimation}

Permeability is a measure of the ability of a porous media to transmit fluid. Permeability can be calculated from various established empirical models (e.g., [30] [31] [32] [33] [34]) based on grain size, pore dimensions, mineralogy and surface area, or water saturation [24] [35]. Permeability estimation in this study was estimated by using Timur [32] model gives as

$$
K=0.136 \frac{\phi^{4.4}}{S_{w i r}^{2}}
$$

where $K=$ Permeability in $\mathrm{mD}, \phi=$ Porosity and $S_{\text {wir }}=$ Irreducible water saturation Irreducible water saturation was estimated from Crain's method [36] 
using the equation below:

$$
S_{\text {wirr }}=\frac{\phi \times S_{w}}{\phi_{e f f}}
$$

where $\phi \times S_{w}$ represents the bulk volume of water (BVW).

\subsubsection{Net/Gross Estimation}

The gross reservoir thickness $H$, of the Mpera well was determined by looking at tops and bases of the reservoir sands across the well. The net reservoir thickness, which is the thickness of the reservoir, was determined by defining basis for non-reservoir and reservoir sands using the gamma ray log. This was carried out by drawing a shale and sand baseline on the gamma ray log and using a combination of neutron and density logs in lithology computation. The thicknesses of the shale, hshale, within the reservoir sands were obtained and thereafter subtracted from the gross reservoir thickness. The Net reservoir thickness equation is given as

$$
\begin{gathered}
h=H-\text { hshale } \\
\text { Net } / \text { Gross }=h / H
\end{gathered}
$$

\section{Results and Interpretations}

\subsection{Qualitative Interpretation}

\subsubsection{Zones Created and Lithology Interpretation}

The first step in well logs interpretation involved selection of zones by making a keen observation of zones of interest, which was composed of mainly sandstone, and shale rocks. From keen observations of logs three zones were encountered and named as Zone 1, Zone 2 and Zone 3 with depths range from $2842.832 \mathrm{~m}$ to $2945.375 \mathrm{~m}, 3009.341 \mathrm{~m}$ to $3042.195 \mathrm{~m}$ and $3084.258 \mathrm{~m}$ to $3097.947 \mathrm{~m}$ respectively (Figures $3(\mathrm{~b})-5(\mathrm{~b})$ ). These zones are composed of reservoir and
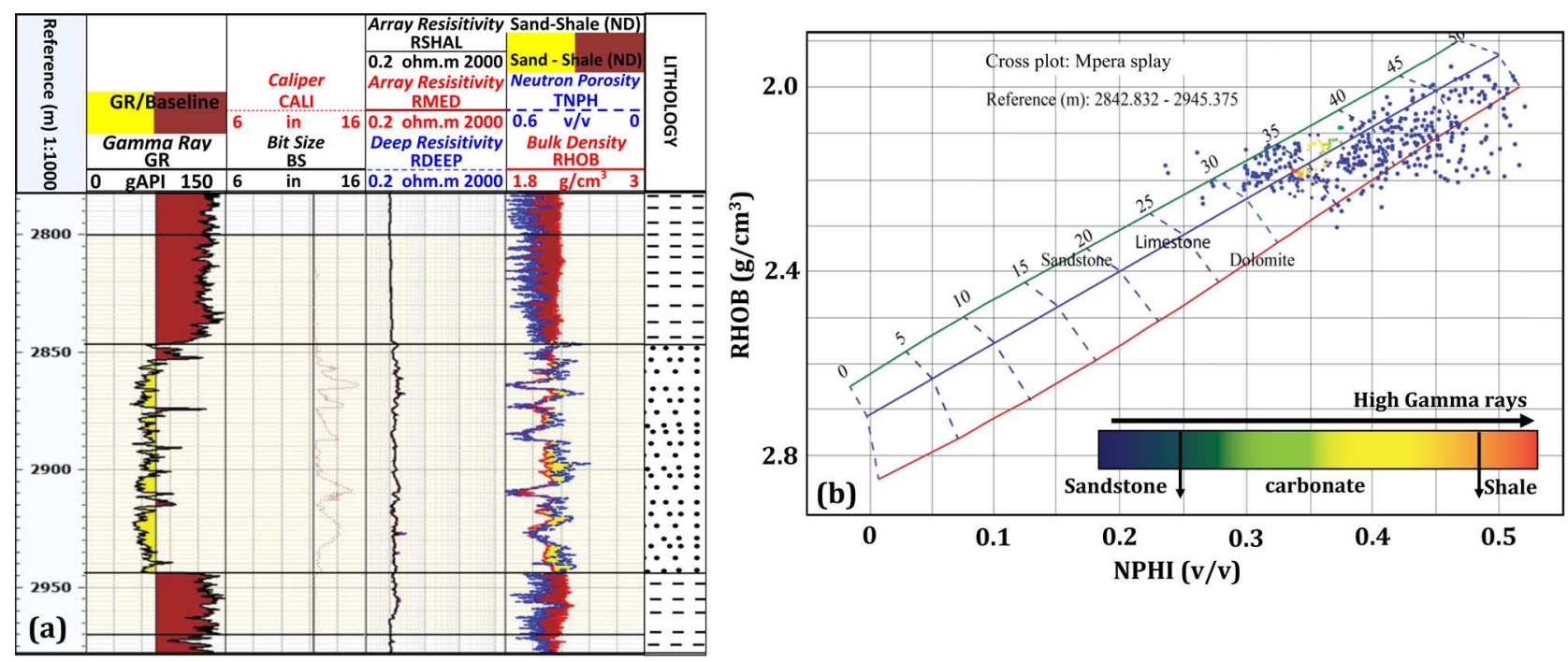

Figure 3. Lithological type identified from (a) Wire line log curves (b) Neutron-Density plot. 

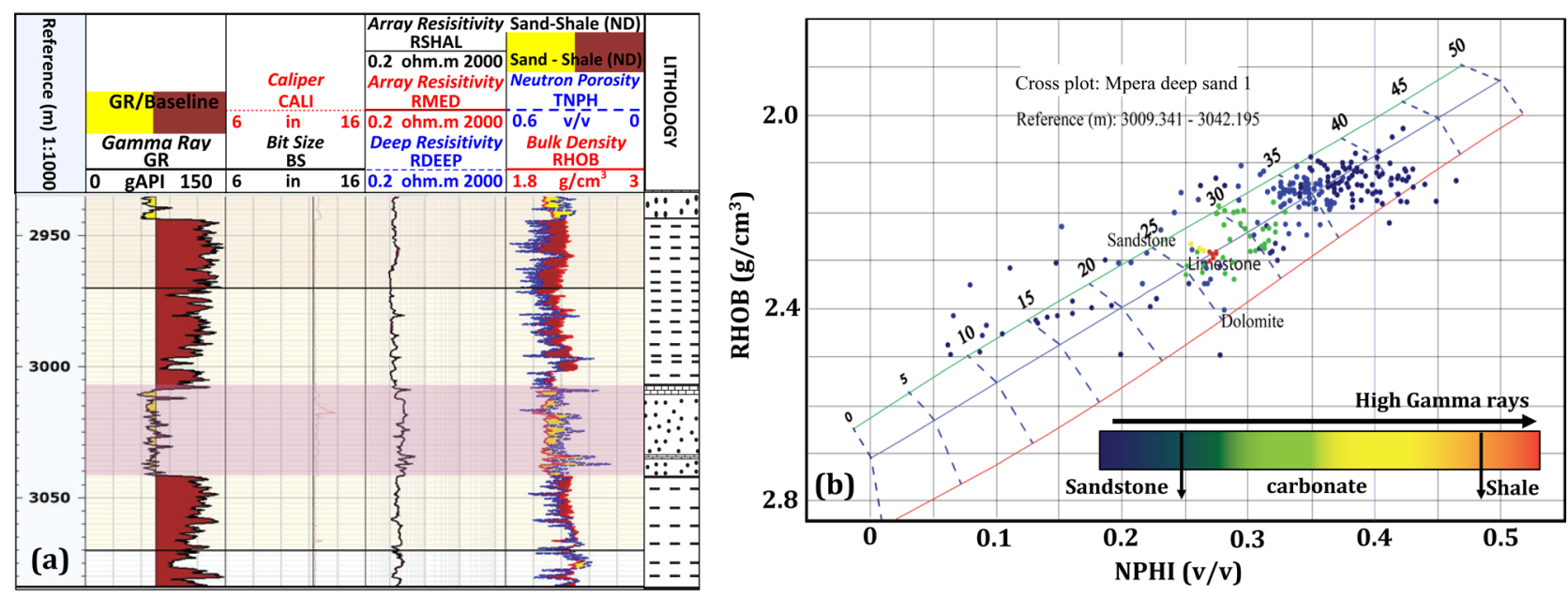

Figure 4. Lithological type identified from (a) Wire line log curves (b) Neutron-Density plot.
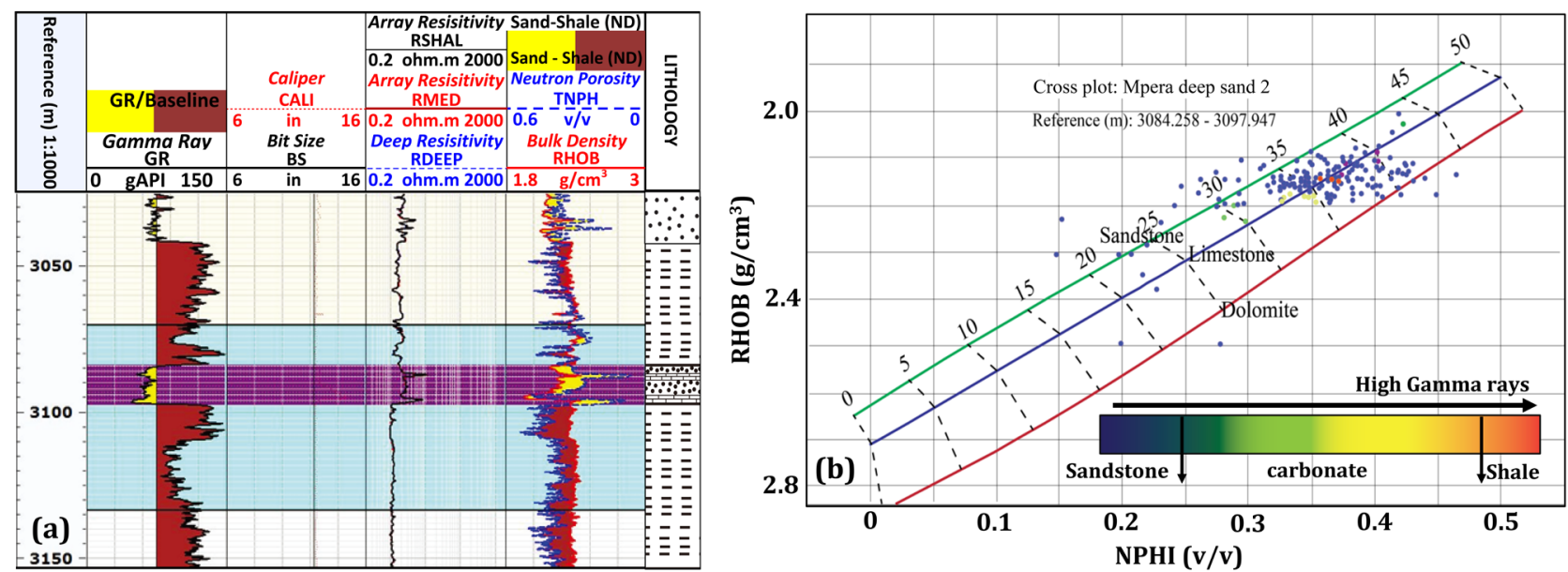

Figure 5. Lithological type identified from (a) Wire line log curves (b) Neutron-Density plot.

non-reservoir units. Based on observed characteristics of caliper, sonic logs, resistivity logs and bit size together with the neutron-density cross plot, three lithological units were identified at Mpera well, which are sandstone, Claystone/shale, and limestone (see Figures 3-5).

Within three zones identified, three reservoir rocks were also identified with their tops and bases ranging from $2842.832 \mathrm{~m}$ to $2945.375 \mathrm{~m}, 2945.375 \mathrm{~m}$ to $3009.341 \mathrm{~m}$ and $3000 \mathrm{~m}$ to $3159.423 \mathrm{~m}$ and are named as Mpera splay, Mpera deep sand 1 and Mpera deep sand 2 respectively (Figures 3-5). In all reservoir zones gamma ray readings were observed to be high in shale rocks and low gamma ray value in sandstone rocks in which low gamma ray indicates permeable zone and high gamma ray indicates impermeable zone. Moreover, the resistivity logs show high picks similar to neutron density logs, which indicate permeable zone. Furthermore, caliper log reads high in when gamma ray reads low and the neutron-density logs show negative separation indicating permeable reservoir rock. 


\subsubsection{Volume of Shale, Porosity, Saturation and Permeability}

The volume of shale from three reservoir rocks was determined using gamma ray $\log$ method. In this method non-linear Clavier model [28] was used in calculation of the volume of shale. Results show that Mpera splay, Mpera deep sand 1 and Mpera deep sand 2 have generally low volume of shale except in shale patches within sandstone formation, which shows high volume of shale (Figure 6). It is important to estimate the shale volume since shale is an impermeable rock, which greatly influences the quality of the reservoir, as well as vertical and horizontal fluid flow during production.

The porosity results indicate that Mpera splay; Mpera deep sand 1 and Mpera deep sand 2 have generally good porosity. The porosity of Mpera splay reservoir ranges from $3.5 \%$ to $30 \%$, Mpera deep sand 1 ranges from $1.5 \%$ to $25 \%$ and that of Mpera deep sand 2 ranges from 6\% to 34\% (Figure 6). Spatial variation in permeability of a rock is very crucial in characterization of reservoir rock, simulation and in calculating the net pay. The permeability results of Mpera well in identified reservoir rocks are generally low as presented in the log curves (Figure 6). The values range from $0.02 \mathrm{mD}$ to $34 \mathrm{mD}, 0.01 \mathrm{mD}$ to $10 \mathrm{mD}$ and $0.01 \mathrm{mD}$ to $50 \mathrm{mD}$ for Mpera splay, Mpera deep sand 1 and Mpera deep sand 2 respectively. Observations made in the permeability log show that Mpera splay has high permeability compared to Mpera deep sand 1 and Mpera deep sand 2.

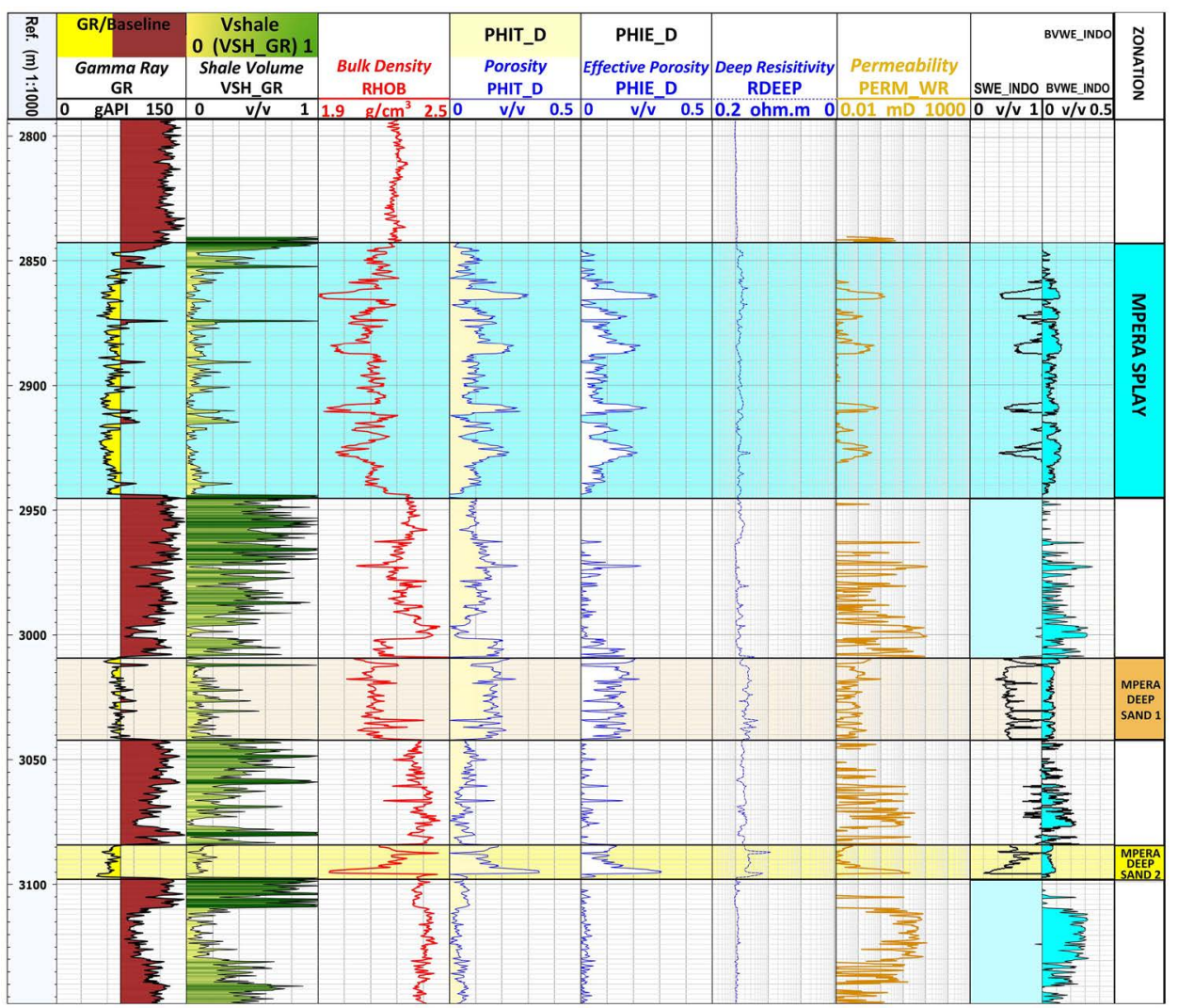

Figure 6. Well log curves showing computed petrophysical parameters for Mpera splay, Mpera deep sand 1 and Mpera deep sand 2 reservoir rocks. 
Water saturation was calculated by using Indonesian method and results indicate that Mpera splay has higher value compared to Mpera deep sand 1 and Mpera deep sand 2 and decreases with increasing depth. This observation shows that Mpera splay reservoir could lack hydrocarbons due to high water saturation. The resistivity of formation water $(R w)$ was obtained using Temperature log as an input in all reservoir zones where $R w$ for Mpera splay was marked as 0.18 ohms where that of Mpera deep sand 1 and Mpera deep sand 2 was marked as $0.27 \mathrm{ohms}$.

\subsection{Quantitative Results}

The petrophysical parameters computed from three identified reservoir zones varies from one reservoir zone to another. The summary of results computed for the volume of shale, porosity, water saturation and permeability are given in Figure 7. The average volume of shale for each reservoir zone calculated from Gamma ray $\log$ is $0.257 \mathrm{v} / \mathrm{v}, 0.235 \mathrm{v} / \mathrm{v}$ and $0.097 \mathrm{v} / \mathrm{v}$ for Mpera splay, Mpera deep sand 1 and Mpera deep sand 2 respectively. The average total and effective porosity computed from density log for all reservoirs range from $0 \%-30.2 \%, 2 \%-20 \%$ and $5 \%$ - 30\% for Mpera splay, Mpera deep sand 1 and Mpera deep sand 2 respectively. The water saturation results obtained from Indonesian model was observed to be $97.6 \%, 92.4 \%$ and $90.6 \%$ for Mpera splay, Mpera deep sand 1 and Mpera deep sand 2 respectively. The average permeability computed from Wyllie and Rose [31] model show fair result ranging from $4.67 \mathrm{mD}$ to $9.47 \mathrm{mD}$.

\section{Discussion}

\subsection{Lithology and Reservoir Zones}

The qualitative interpretation of well logs for Mpera well started with the

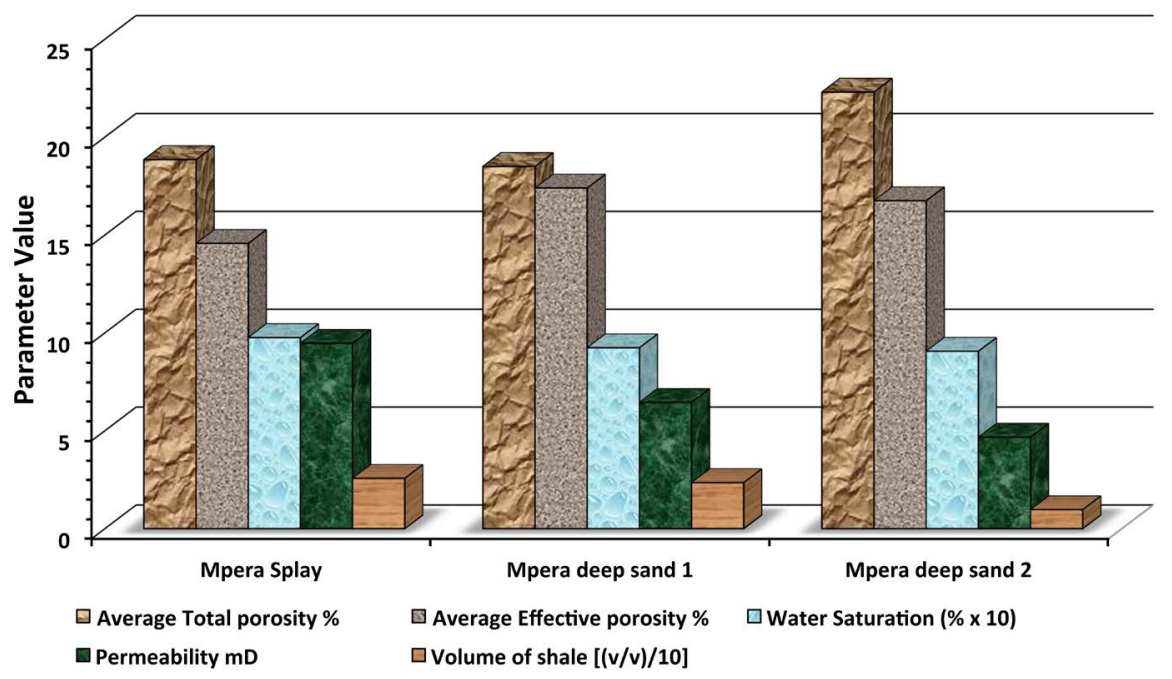

Figure 7. Relationship between average total and effective porosity, water saturation, permeability and volume of shale of Mpera splay, Mpera deep sand 1 and Mpera deep sand 2 reservoir zones. 
lithology interpretation in order to differentiate between free shale lithology and shale formation. Lithology encountered for Mpera well are shale (probably claystone) and free shale lithology. The shale formation is characterized strongly by three important factors; high gamma ray [13] [22], positive separation on neutron-density logs and separation between deep and shallow resistivity logs. In limestone lithology, neutron-density logs overlay each other [26] [37] and when the formation is impermeable (shale) the deep and shallow resistivity logs show superimposition [27].

In order to know the types of rocks in a reservoir rock, neutron-density cross plots were plotted. From the cross plots two free shale lithologies were encountered which are limestone and sandstone with some dolomite cements. The dolomite occurred as cement while sandstone and limestone are the dominant lithology. The interpreted lithology in this study indicated by clear sand bodies, interbedded with shales resembles the on-lapping structural closures as observed in the stratigraphic sequence of the offshore basins from Samson [21]. Three reservoir rocks were identified in this study, which include Mpera splay, composed of only sandstone interbedded with shale; Mpera deep sand 1, composed of sandstone with limestone and Mpera deep sand 2 that consists of sandstone and limestone. The reservoir rocks identified in the study resembles the regional described reservoir rocks that consist of Cretaceous sandstone and Tertiary deltaic sandstone with limestone [10] [12].

\subsection{Petrophysical Parameters}

In Mpera well, the net-gross ratio for the three reservoirs Mpera splay, Mpera deep sand 1 and Mpera deep sand 2 are 91.9\%, 87.9\% and 94.2\% respectively indicative of a producible reservoir thickness. On the other hand, the bulk water volumes for the three reservoirs are $14.2 \%, 16.1 \%$ and $15.1 \%$ respectively indicating that most of the pores are occupied by water only. On using resistivity logs, zones of possible oil accumulation were indicated by high resistivity values whereas water zones were indicated by low resistivity values [26]. If the porosity is filled with fluid the neutron log measures the type of liquid that fills the pores [26] and the neutron porosity log in this study shows the presence of water only. The water saturation estimated from this study are $97.6 \% 92.4 \%$ and $90.6 \%$ for Mpera splay, Mpera deep sand 1 and Mpera deep sand 2 respectively, which indicate that all three reservoirs are saturated with water. Average volume of shale at Mpera splay, Mpera deep sand 1 and Mpera deep sand 2 are $25.7 \%, 23.5 \%$ and 9.7\% respectively, which indicate good reservoir quality. The obtained average porosity values in this study for Mpera splay, Mpera deep sand 1 and Mpera deep sand 2 are $18.85 \%, 18.5 \%$ and $22.3 \%$ respectively, which according to Rider [26] are termed as good porosity.

The permeability estimated in this study for Mpera splay, Mpera deep sand 1 and Mpera deep sand 2 are $9.47 \mathrm{mD}, 6.45 \mathrm{mD}$ and $4.67 \mathrm{mD}$ respectively. This clearly shows that all values fall on poor to fair permeability [26]. On the other 
hand, the permeability values show slight decrease with depth from Mpera splay to Mpera deep sand 1 but become high down to Mpera deep sand 2 due to the presence of limestone in this zone, most likely as a result of diagenesis, compaction and dissolution associated with depth of burial. Moreover, the low permeability could also be attributed to the geology of the area where clays with very fine grains tend to fill in pore spaces between sand particles. This causes reduction in porosity and permeability, which are the main parameters for the potentiality of hydrocarbon reservoir rocks. The combination of porosity and permeability results indicate that pores are not interconnected in the reservoir rocks. Although the porosity of the reservoir encountered was found to be good $(\sim 20 \%)$; with good reservoir quality, the high water content and poor to fair permeability results in all reservoir indicate that they are non-economical hydrocarbon reservoirs.

\section{Conclusions}

The characterization of reservoirs by a detailed petrophysical parameter estimation reveals that the reservoir quality is strongly influenced by the presence of sand bodies/reservoir rocks as a result of the presence of high values of porosity and permeability. With this in context the petrophysical evaluation of the Mpera well reservoir rocks indicates that the porosity is generally good while the permeability is poor. Results further indicate a gradual variation in porosity with the lowest porosity at Mpera deep sand 1, highest porosity value in Mpera deep sand 2 and medium porosity at Mpera splay. On the other hand the permeability values show slight decrease with depth from Mpera splay to Mpera deep sand 1 but become high down to Mpera deep sand 2 due to the presence of limestone in this zone, most likely as a result of diagenesis, compaction and dissolution associated with depth of burial of the older sediments as deposition occurred. The low permeability values could also be attributed to the geology of the area where clays tend to fill in pore spaces between sand particles causing reduction in porosity and permeability. The parameters are vital for the potentiality of hydrocarbon reservoir rocks.

The water saturation value generally goes up to $97.6 \%$ in average, while the hydrocarbon saturation of the well is less than $10 \%$ in average. The values of the bulk volume of water combined with water saturation imply that all reservoirs are saturated with water. The findings generally indicate low quality reservoir rocks with no hydrocarbon bearing such that it could not be potential for hydrocarbon production. According to this study, it can be clearly found that the area is not potential for hydrocarbon exploration due to the fact that petrophysical parameters are not in accord with the potentiality of the hydrocarbon in the area.

\section{Acknowledgements}

The authors are grateful to BG Group for funding this research as part of MSc. 
program. We thank Tanzania Petroleum Development Company (TPDC) for providing the data used in this study. We also thank many individuals from the University of Dar es Salaam and TPDC for their assistance in completion of this work. We also thank the anonymous reviewer for constructive comments.

\section{References}

[1] Helby, R. (1987) Three Late Triassic Palynomorphs from Northwestern Australia. Association of Australasian Palaeontological Memoirs, 4, 95-100.

[2] Foster, C.B., Balme, B.E. and Helby, R. (1994) First Record of Tethyanpalynomorphs from the Late Triassic of East Antarctica. AGSO Journal of Australian Geology \& Geophysics, 15, 239-246.

[3] Geiger, M., Clark, D.N. and Mette, W. (2004) Reappraisal of the Timing of the Breakup of Gondwana Based on Sedimentological and Seismic Evidence from the Morondava Basin, Madagascar. Journal of African Earth Sciences, 38, 363-381. https://doi.org/10.1016/j.jafrearsci.2004.02.003

[4] Kent, P.E., Hunt, J.A. and Johnstone, D.W. (1971) Geology and Geophysics of Coastal Sedimentary Basins of Tanzania. Institute of Geological Sciences, London, $1-101$.

[5] Balduzzi, A., Msaky, E., Trincianti, E. and Manum, S.B. (1992) Mesozoic Karoo and Post-Karoo Formations in the Kilwa Area, Southeastern Tanzania-A Stratigraphic Study Based on Palynology, Micropaleontology and Well Log Data from the Kizimbani Well. Journal of African Earth Sciences, 15, 405-427.

https://doi.org/10.1016/0899-5362(92)90025-8

[6] Reeves, C. and De Wit, M. (2000) Making Ends Meet in Gondwana: Retracing the Transforms of the Indian Ocean and Reconnecting Continental Shear Zones. Terra Nova, 12, 272-280. https://doi.org/10.1046/j.1365-3121.2000.00309.x

[7] Salman, G. and Abdula, I. (1995) Development of the Mozambique and Ruvuma Sedimentary Basins Offshore Mozambique. Sedimentary Geology, 96, 7-41. https://doi.org/10.1016/0037-0738(95)00125-R

[8] Bumby, A.J. and Guiraud, R. (2005) The Geodynamic Setting of the Phanerozoic Basins of Africa. Journal of African Earth Sciences, 43, 1-12. https://doi.org/10.1016/j.jafrearsci.2005.07.016

[9] Teixeira, L., Martinez, V. and Chrispin, S. (2009) Tanzania Utra-Deepwater Exploration. Search and Discovery, 1-9.

[10] Zongying, Z., Ye, T., Shujun, L. and Wenlong, D. (2013) Hydrocarbon Potential in the Key Basins in the East Coast of Africa. Petroleum Exploration Development, 40, 582-591.

[11] Mpanju, F. and Philp, R.P. (1994) Organic Geochemical Characterization of Bitumens, Seeps, Rock Extracts and Condensates from Tanzania. Organic Geochemistry, 21, 359-371. https://doi.org/10.1016/0146-6380(94)90198-8

[12] Zhixin, W., Zhaoming, W., Chengpeng, S., Zhengjun, H. and Xiaobing, L. (2015) Structural Architecture Differences and Petroleum Exploration of Passive Continental Margin Basins in East Africa. Petroleum Exploration and Development, 42, 733-744. https://doi.org/10.1016/S1876-3804(15)30070-7

[13] Asquith, G.B. and Gibson, C.R. (1982) Basic Well Log Analysis for Geologists. The American Association of Petroleum Geologists (AAPG), Tulsa.

[14] Amante, C. and Eakins, B.W. (2009) ETOPO1 1 Arc-Minute Global Relief Model: 
Procedures, Data Sources and Analysis. NOAA Technical Memorandum NESDIS NGDC-24.

[15] Cochran, J. (1988) Somali Basin, Chain Ridge, and Origin of the Northern Somali Basin Gravity and Geoid Low. Journal of Geophysical Research: Solid Earth, 93, 11985-12008. https://doi.org/10.1029/JB093iB10p11985

[16] Nyagah, K. (1995) Stratigraphy, Depositional History and Environments of Deposition of Cretaceous through Tertiary Strata in the Lamu Basin, Southeast Kenya and Implications for Reservoirs for Hydrocarbon Exploration. Indian Ocean Basins Margins, 96, 43-71.

[17] Plummer, P.S. and Belle, E.R. (1995) Mesozoic Tectono-Stratigraphic Evolution of the Seychelles Microcontinent. Indian Ocean Basins Margins, 96, 73-91.

https://doi.org/10.1016/0037-0738(94)00127-G

[18] Pearson, P.N., Nicholas, C.J., Singano, J.M., Bown, P.R., Coxall, H.K., van Dongen B.E., Huber, B.T., Karega, A., Lees, J.A. and MacLeod, K. (2006) Further Paleogene and Cretaceous Sediment Cores from the Kilwa Area of Coastal Tanzania: Tanzania Drilling Project Sites 6-10. Journal of African Earth Sciences, 45, 279-317. https://doi.org/10.1016/j.jafrearsci.2006.02.005

[19] Nicholas, C.J., Pearson, P.N., McMillan, I.K., Ditchfield, P.W. and Singano, J.M. (2006) Structural Evolution of Southern Coastal Tanzania since the Jurassic. Journal of African Earth Sciences, 48, 273-297. https://doi.org/10.1016/j.jafrearsci.2007.04.003

[20] Mpanda, S. (1997) Geological Development of the East African Coastal Basin of Tanzania. Stockholm Contributions in Geology, 45, 11-108.

[21] Sansom, P. (2016) Sequence Stratigraphic Scheme for the Jurassic-Neogene of Coastal and Offshore Tanzania. Research to Reserves, 1, 33-37.

[22] Serra, O. (1986) Fundamentals of Well-Log Interpretation. 2. The Interpretation of Logging Data, Developments in Petroleum Science. Developments in Petroleum Science 15B, Elsevier, Amsterdam, 684 p.

[23] Tiab, D. and Donaldson, C. (1997) Theory and Practice of Measuring Reservoir Rock and Fluid Transport Properties. 2nd Edition, Houston, Texas.

[24] Ellis, D.V. and Singer, J.M. (2008) Well Logging for Earth Scientists. 2nd Edition, Springer, Berlin.

[25] Bassiouni, Z. (1994) Theory, Measurement and Interpretation of Well Logs. Textbook Series, Vol. 4, Society of Petroleum Engineers (SPE).

[26] Rider, M.H. (1979) The Geological Interpretation of Well Logs. 2nd Edition, Blackie Glasgow and London John Wiley and Sons, New York.

[27] Ulasi, A.L., Onyekuru, S.O. and Iwuagwu, C.J. (2012) Petrophysical Evaluation of Uzek Well Using Well Log and Core Data, Offshore Depobelt, Niger Delta, Nigeria. Advances in Applied Science Research, 3, 2966-2991.

[28] Clavier, C., Hoyle, W. and Meunier, D. (1971) Quantitative Interpretation of Thermal Neutron Decay Time Logs: Part I. Fundamentals and Techniques. Journal of Petroleum Technology, 23, 743-755. https://doi.org/10.2118/2658-A-PA

[29] Poupon, A. and Leveaux, J. (1971) Evaluation of Water Saturation in Shaly Formations. The Log Analyst, 12, 1-2.

[30] Tixier, M.P. (1949) Evaluation of Permeability from Log Resistivity Gradients. Oil and Gas Journal, 48, 113-122.

[31] Wyllie, M.R.J. and Rose, W.D. (1950) Some Theoretical Considerations Related to Quantitative Evaluation of Physical Characteristics of Reservoir Rocks from Elec- 
trical Log Data. Transactions of the AIME, 189, 105-118.

[32] Timur, A. (1948) An Investigation of Permeability, Porosity, and Residual Water Saturation Relationships for Sandstone Reservoirs. The Log Analyst, 9, 3-5.

[33] Coats, G.R. and Dumanoir, J.L. (1974) A New Approach to Improved Log-Derived Permeability. The Log Analyst, 15, 17-31.

[34] Coats, G.R. and Denoo, S. (1981) The Producibility Answer Product. The Technical Review, 29, 55-144.

[35] Mohaghegh, S., Balan, B. and Amerl, S. (1997) Permeability Determination from Well Log Data. SPE Formation Evaluation Journal, 12, 170-174. https://doi.org/10.2118/30978-PA

[36] Crain, E.R. (1986) The Log Analysis Hand Book. Penn-Well, Publ. Co., Tulsa.

[37] Crain E.R. (2016) Visual Analysis Rule for Water Saturation, Petrophysical Handout. https://www.spec2000.net/00-404-redirect.htm 